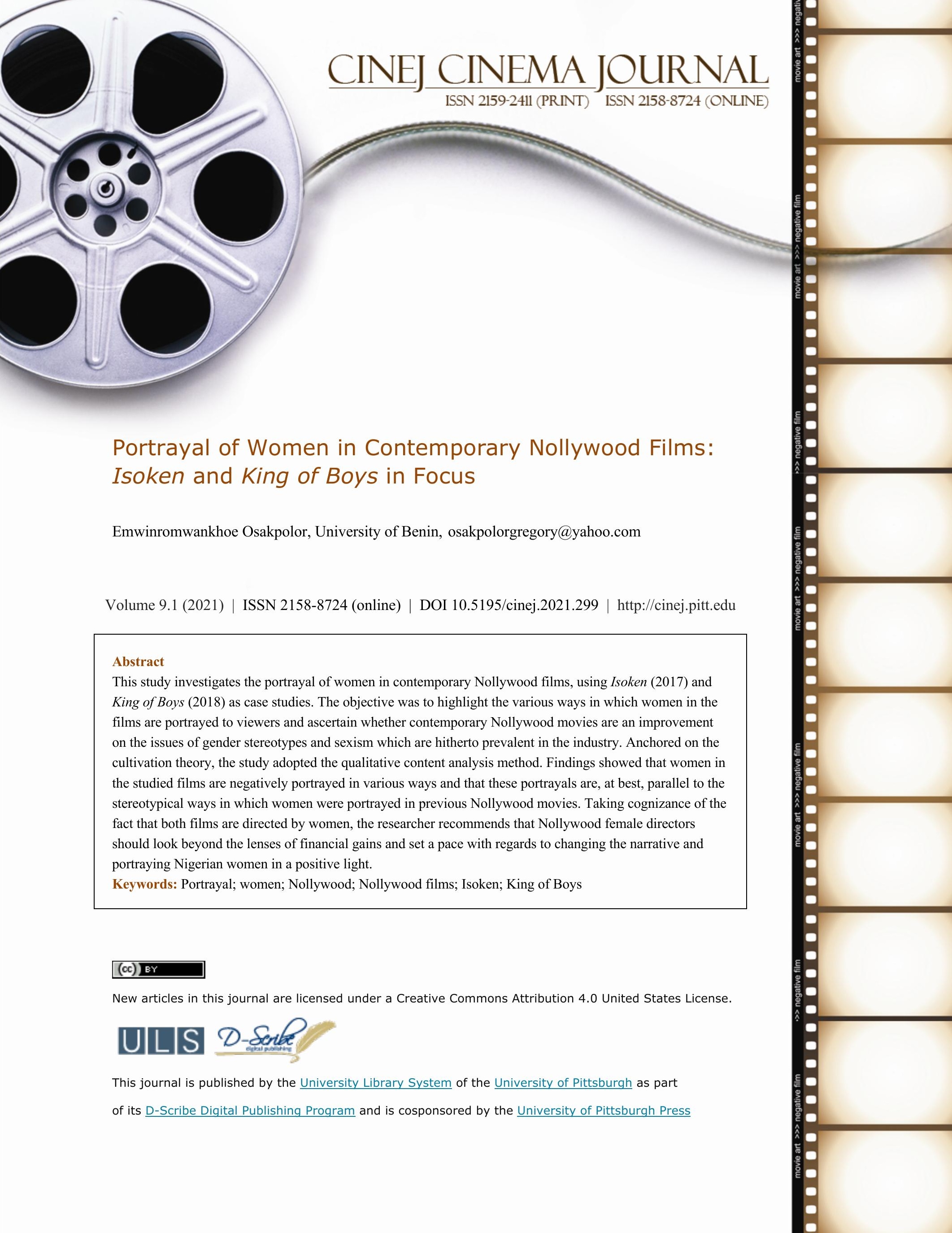




\section{Portrayal of Women in Contemporary Nollywood Films: Isoken and King of Boys in Focus Emwinromwankhoe Osakpolor}

\section{Introduction}

Film, also referred to as movie, motion picture, theatrical film or photo-play, is unarguably a medium of mass communication. As a popular and veritable mass medium, it performs the tripartite role of information, education and entertainment (Ekwuazi, 2007; Kurki \& Dahiru, 2020). A film not only plays a role in the education and indoctrination of citizens in a country, but also helps in the formation of ideas, attitudes as well as the representation of religions, cultures and ideologies (Perkins, 2000; Ibrahim, 2013; Uzuegbunam \& Ononiwu, 2018).

As Ibrahim (2013) rightly notes, the film is a potent medium through which pertinent ideas, norms and values are relayed to people across various parts of the globe. Arguing in this line, Uzuegbunam \& Ononiwu (2018) observe that a film can harbour ideologies, empathy, misconceptions, beliefs and stereotypes which can be uncovered with critical eyes. In films, men and women are usually portrayed in different ways, depending on the mindset, ideology and goal of the person telling the story. As Dehchenari, Abdullah \& Eng (2014) opine, gender stereotypes in films are very influential and they affect people's conceptualisation of men and women as well as establish social categories for both genders.

CINEJ Cinema Journal: Portrayal of Women in Contemporary Nollywood Films: Isoken and King of Boys in Focus

Volume 9.1 (2021) | ISSN 2158-8724 (online) | DOI 10.5195/cinej.2021.299| http://cinej.pitt.edu 
Previous studies (Adamu, 2007; Dehchenari, Abdullah \& Eng, 2014; Aromona, 2016;

Afolabi \& Oyero, 2017; Ibbi, 2017; Uzuegbuna \& Ononiwu, 2018; Onyenankeya, Onyenankeya \& Osunkunle, 2019; Kurfi \& Dahiru, 2020) have also established the fact that the way people, ideas and objects are portrayed in films affects the way viewers perceive the people, ideas and objects in real life. Men, for instance, are generally stereotyped as competent, assertive, independent and achievement-oriented whereas women are generally stereotyped as warm, sociable, muted, wicked, interdependent and relationship-oriented (Langford \& Mackinnon, 2000; Dehchenari, Abdullah \& Eng, 2014; Aromona, 2016).

There is no telling the fact that the Nigerian Film Industry, popularly referred to as Nollywood, has emerged to become the most popular film industry in Africa. Nollywood is the third largest film industry in the world, behind only Hollywood in America and Bollywood in India (Ekwuazi, 2007; Aromona, 2016; Kurfi \& Dahiru, 2020). The means of production and consumption of Nollywood movies have undoubtedly gone a long way in redefining African Cinema. This is the ostensible reason why Nollywood keeps attracting the attention of film scholars and film critics across the globe (Kumwenda, 2007; Ekwuazi, 2010).

As is obtainable in other film industries across various parts of the world, Nollywood movies portray men and women in different light to viewers. Scholars (Okunna, 1996; Kumwenda, 2007; Aromona, 2016; Omatsola, 2016; Ibbi, 2017; Onyenankeya, Onyenankeya \& Osunkunle 
2019) argue that the norm, especially for movies that were released before 2017 , is the portrayal

of women as weak, dependent, cheap, wicked, relationship-oriented and opportunist folks. Other representations of females in the aforesaid period include full-time house wife, witches, prostitutes and objects of ritual and sexploitation by men (Kumwenda, 2007; Aromona, 2016; Omatsola, 2016; Ibbi, 2017).

However, while much is known about the portrayal of women in Nollywood movies that were released before 2017, little is actually known about women's portrayal in Nollywood movies that have been released in contemporary times (especially between 2017 and 2018). Against this backdrop, this study sought to investigate the portrayal of women in contemporary Nollywood movies, using Isoken (2017) and King of Boys (2018) as reference points.

\section{Theoretical Underpinning}

This study is anchored on the cultivation theory. The theory, also known as cultivation hypothesis or cultivation analysis (Matei, 2012; Asemah, Nwammuo \& Uwaoma, 2017), was originally propounded by Professor G. Gerbner, Dean of Annenberg School of Communications. Professor Gerbner was later joined by Larry Gross during the 60's (Johnson, 2011; Asemah, Nwammuo \& Uwaoma, 2017). 
The central tenet of cultivation theory is that people's social construction of reality is primarily shaped by what they what they see on television (Nwuneli et al, 1993; Okunna, 1996; Morgan, Signorielli \& Shanahan, 2002; Aromona, 2016). Put in another way, the more people spend time watching programmes on television, the more likely they are to believe the social reality of people, places and things portrayed via the medium. According to Gerbner and Gross (1976), cited in Asemah, Nwammuo and Uwaoma (2017), the mass media, particularly television, speaks to audiences and maintains the society through images and ideas. The cultivation theory, therefore, explains how people's conceptions of social reality are influenced according to their exposure on television (Zaharopoulos, 2001). The theory simply assumes that people's attitudes are forged in the hours they watch television especially in the direction in which the content flows ideologically.

Albeit Gerbner and his team focused their research on just fictional television, scholars have, in recent times, expanded cultivation research into additional media such as video games and cinematic films (Hernandez, 2012; Vinney, 2019). Vinney goes further to state that film scholars have particularly found the cultivation theory useful in their bid to analyse how the portrayal of each gender affects the way the audience perceive such gender. Hernandez (2012) who conducted a research to investigate how college students' attitudes about the dating process were shaped by their exposures to cinematic films, averred that the cultivation theory becomes 
very handy when a researcher intends to describe how people's attitudes are shaped by their exposure to cinematic films.

With regards to cinema and films, cultivation theory is particularly used as a theoretical foundation for research on crime, gender, stereotypes, body ideals, and politics (Okunna, 1996; Aromona, 2016; Vinney, 2019). Studies on gender and sex roles stereotypes have greatly relied on the cultivation theory to investigate the ways in which contents in cinematic films have perpetuated the different portrayals of men and women (Harrison, 2003; Hernandez, 2012; Vinney, 2019). Studies (Gallagher, 1995; Agbese, 2010; Hernandez, 2012; Aromona 2016) have also shown that viewers of cinematic films invariably cultivate negative perceptions and attitudes from the stereotypical contents presented on the medium.

The cultivation theory, therefore, is very pertinent to this study as it helps shed light on the stereotypical portrayal of women in the selected contemporary Nollywood films.

\section{Ways in Which Women Were Portrayed in Nollywood Films Released before 2016}

A critical look at the Nollywood Film Industry as well as the films churned out before 2016 has revealed that the portrayal of women has never gone beyond the traditional line which strongly accentuates male chauvinism and patriarchy. For instance, Aromona (2016), after conducting a 
research on the portrayal of African women in Nollywood films over a five-year period, found that there has not been a shift in the traditional way in which women are represented in the industry. Aromona's finding is corroborated by Onyenankeya, Onyenankeya \& Osunkunle (2019) whose in-depth study on Nollywood films shot over two decades (1997-2016) revealed that there has not been any major shift in the way women are stereotypically represented in the films.

First and foremost, women during the aforesaid period were portrayed as sexual objects. This sexual objectification manifests in the way female characters were dressed and addressed in the films. In a study carried out by the Geena Davis Institute on Gender and Media (2015), it was found that women in Nollywood films are often dressed in skimpy attires, and are more likely to be depicted as prostitutes than male characters. Sexism, sexual gratification and objectification were woven into movies released during the period in both manifest and latent ways (Ogunranti, 1981; Brock, 2009; Onyenankeya, Onyenankeya \& Osunkunle, 2019).

Another way Nigerian women were portrayed in such films were as wives or homemakers; nothing more and, of course, nothing less. As Onyenankeya, Onyenankeya \& Osunkunle (2019) observed, the images of female characters shown in such Nollywood films were those of contented women whose major life ambition was to produce and bear children. The women were portrayed as unambitious domestic servants and, as long as they remained in that state, they were seen as good and responsible wives. But when the women decided to be ambitious and make names for 
themselves in their respective fields, they were seen as bad and irresponsible. Okuyade (2011) whilst painting a vivid picture of this scenario, made reference to a popular Nollywood film entitled End of the Wicked. He stressed that in the film, there was the dependent woman whose bliss could only be tied to her need to bag a husband.

Also, women were often depicted as weak and dependent folks. Olupohunda (2013) argued that women in Nollywood films were typically at the mercy of the men who dominated the society in such films. As such, these women could be slapped, kicked, raped and maimed. On the contrary, in instances where the films promoted the progress made by women either in the political or economic arena, they were constantly reminded that their success was nothing unless they conformed to the social construct of good women in their domestic lives (Abbah 2008). Duru (2013) and Onyenankeya, Onyenankeya \& Osunkunle (2019) also opined that when females were cast as independent folks or feminists, they were portrayed as self-centred and materialistic, while men were typically shown as heroes who rescued the community from the clutches of these liberated women.

Furthermore, women were regularly depicted as the "silent ones." They were muted and portrayed as folks who could be seen but never heard. As such, their actions and inactions were 
often questioned by the men around them. This representation was, of course, in sharp contrast to that of the male folks who were often portrayed as bold, courageous and assertive.

In addition, women were portrayed as wicked, treacherous and extremely dangerous folks.

This depiction was often brought to light whenever women were shown in positions of power - be it in the business or political arena. As Haynes \& Okome (1998), Ukata (2010) and Duru (2013) asserted, powerful women were often seen as deceitful, cruel and dangerous persons. The scholars added that these women always attracted some reprisal from the males for the simple reason that they dared to be successful. Thus, being powerful always had some negative consequences for female characters, which could be in form of loss of their beauty, family and, in some cases, their lives (Ukata, 2010). Nollywood films, therefore, presupposed that power, in the hands of a woman, was very execrable.

\section{Methodology}

The researcher adopts the qualitative content analysis to study the selected films - Isoken (2017) and King of Boys (2018). Both films were purposively selected because they stand out in various ways. Firstly, they both have women as protagonists. This feature makes it easier for the researcher to beam an analytical searchlight on the lead characters as well as other women who played prominent roles in the films. Secondly, the films were directed by females. Owing to the 
fact that many film scholars (Ukata, 2010; Duru, 2013; Olupohunda, 2013; Omatsola, 2016; Elegbe 2017; Ibbi, 2017; Onyenankeya, Onyenankeya \& Osunkunle, 2019) have attributed the negative portrayal of females in time past to the preponderance of males as directors in the industry, the researcher thought it wise to select films that were directed by females. With women as directors; women telling stories about women, the researcher sought to know whether or not the narrative would change for the better.

Thirdly, they are both very popular Nollywood films. The films were premiered and watched in cinemas within and outside the country. Consequently, the films grossed colossal amounts at the box office. According to statistics from Wikipedia, Isoken was reported to have grossed over 98 million naira whilst King of Boys grossed over 245 million naira.

Lastly, the films are winners of the Africa Movie Academy Awards (AMAA), the most prestigious movie awards for films produced and directed by Africans. The AMAA is generally termed the African version of the Oscars. It is worthy of note that Isoken received six nominations at the 2018 AMAA Award Ceremony and eventually won in three categories - Best Actress in a Lead Role, Achievement in Costume, and Best Nigerian Film. King of Boys, on the other hand, had nine nominations at the 2019 AMAA Award Ceremony out of which the film won in three 
categories - Best Actress in a Lead Role, Best Actress in a Supporting Role, and Best Nigerian Film.

Against this backdrop, the researcher believes that both films are microcosms of the larger category of Nollywood films produced between 2017 and 2018 from which they were selected. The portrayal of women in both films is carefully examined after which conclusion is drawn.

\section{Synopsis of Isoken}

Isoken is a 2017 romantic comedy that is written, produced and directed by Jadesola Osiberu, under Tribe 85 Productions. The film runs for 98 minutes and stars the following persons:

Dakore Akande, Joseph Benjamin, Marc Rhys, Funke Akindele, Lydia Forson, Damilola Adegbite, Tina Mba, Patrick Doyle, Nedu Wazobia, Ayoola Ayolola and Bolanle Olukanni. The film revolves around the life of the eponymous heroine, Isoken (played by Dakore Akande). Born into a family of four (three girls and a boy), Isoken, the eldest child, has to grapple with the challenges that come with not being married at the overripe age of thirty-four. Although she seems to have the perfect kind of life every lady would practically wish for - she is beautiful, intelligent, successful, and surrounded by great family members and friends - her singlehood in a culture that is excessively obsessed with marriage serves as a great source of worry for everyone in her family. 
Her mother, obviously the most concerned of them all, decides to orchestrate a matchmaking between Isoken and Osaze, an Edo man, at the wedding ceremony of Rhema, Isoken's youngest sister. Osaze is good-looking, charming, intelligent, successful and above all, from a very nice and well respected family. Therefore, Isoken's family members see Osaze as the quintessential husband material for Isoken.

Meanwhile, Isoken runs into Kevin, a white man, in what appears to be the most embarrassing of situations: Kevin hands Isoken her underpant which he had found in a dryer at the Laundromat. A few days later, albeit coincidentally, the same Kevin happens to be the photographer drafted by Isoken's company for a grand advertising campaign. Because the campaign demands that Isoken and Kevin work together, both of them had to mingle and in the process, they realise that they have similar passions one of which is music. Based on the advice of Kukwa, one of Isoken's three friends, Isoken decides to simultaneously date Osaze and Kevin.

Not long after, on her thirty-fifth birthday, Osaze proposes marriage to Isoken. This is however to the chagrin of Kevin who had brought her a special birthday present. Events move very fast as the families of Isoken and Osaze make preparations for what seems to be a grand wedding. Isoken, however, feels very weird and confused. She is at a crossroads as she feels that Osaze, though perfect, is not perfect for her. Her quagmire is further compounded when she meets Kevin 
at the naming ceremony of her friend's (Joke's) baby. Kevin, in a moment of passion and display of strong emotions, tells Isoken: “Please, don’t marry him [Osaze]. Don't. Because I love you. And I know you love me too. So, choose us."

Later, at her pre-wedding dinner, Isoken summons courage and tells Osaze that she cannot go ahead with the wedding. Her action stirs up a hornets' nest in the household. In the family meeting that followed, Isoken discloses that she broke up with Osaze because she loves someone else who is white (oyinbo). Her family is flabbergasted and her mother, in a moment of shock, asks her why she decided not to be normal like her sisters.

The meeting, nevertheless, ends abruptly when Isoken reveals that she is going to tell Kevin, who plans to leave the country the day after, that she loves him. Accompanied by her family members (including her mother), Isoken professes her love for Kevin. Kevin responds with an ardent kiss as well as hug which makes the lovebirds become a cynosure of all eyes.

\section{Portrayal of Women in Isoken}

Isoken as a movie is replete with lucid scenes that do not only relegate women to the background, but also present them as folks who cannot but play the second fiddle to their male counterparts. The negative portrayal of women in Isoken is brought to light in the very first scene of the film and runs through the entire film. In the first scene, that is, the wedding ceremony of 
Osato, Isoken's youngest sister, Isoken is constantly reminded by her aunties present that God would provide her a husband. This is because the aunties ostensibly believe that it is very abnormal for Isoken's two younger sisters to get married before her. A particular aunty of hers unequivocally remarks: "My dear, if it were some people, they would have been crying and hiding by now. First, it was your sister Rhema. Now, Osato, your youngest sister. She should have been the one serving at your wedding, not the other way round."

Still in the first scene, Isoken's mother arranges a matchmaking between Isoken and Osaze. This is because she, as well as the other family members, believes strongly that regardless of Isoken's achievements in other areas of life, she is incomplete without a husband. When Isoken begs her Mum to stop what she terms "disastrous matchmaking," her Mum responds: "See your mouth like disastrous. Did you bring a man home?" Isoken's mother's stance, as well as that of the other family members, is a clear reflection of the way the Nigerian society view women who are unmarried at a ripe age. The aforementioned, thus, goes a long way in re-echoing the long and common portrayal of women as persons who should not be reckoned with or heard in the society unless they bag husbands for themselves.

Women are also portrayed as sex objects in the film. This is brought to life when Kukwa, out of her urgent need for a man, flaunts her voluptuous figure to entice Chuks. In the second scene 
of the film as well as a later scene in which Isoken and her friends discuss their urgent need for husbands, Agnes is seductively dressed. Her cleavage, as well as part of her laps, is exposed to the viewers. Not just that; Isoken's friends, on hearing that Isoken would be going for dinner at Osaze's house, persuade her to go for waxing in preparation for their envisaged sexual encounter. Later, when Isoken complains that the whole waxing thing is too painful, Kukwa stresses that she thoroughly enjoys it as Chuks cannot get enough of her. The women, as it is portrayed, believe very much that they are sex objects for the men.

In addition, women are portrayed as persons who should care less about their educational pursuit while they care more about getting married and being good housewives to their husbands. This is evident in the scene in which Isoken, in the midst of other family members, discloses her need to get an executive Master's in Business Administration (MBA) from a foreign university. Her mother, on hearing this, tells her: "Instead of you to come into the kitchen and assist us, you are here talking all over the place. Will MBA find you a husband, or do they dash people children in the university? A woman should not read too much." This picture is very negative because women are very much in need of education as are men.

Even while Isoken and Osaze are dating, Isoken's father pushes Osaze to declare his intentions towards his daughter. This act, for one thing, portrays men as dominant. For another, it speaks of the fact that a woman's family is very swift to let go of a woman who is of marriageable 
age. This, they do not minding how long they have known the suitor or whether they can vouch for him.

Furthermore, women are portrayed as the "silent ones"; that is, folks who should be seen and not heard. This portrayal is brought to the fore when Osaze proposes marriage to Isoken at her birthday bash. Isoken is yet to think about Osaze's proposal when her family members and other invitees echo "YES." They all say "YES" on her behalf because to them, Isoken has absolutely no reason to say "NO" to a man when she is thirty-five years old. They feel that getting married to a man, the man's true character notwithstanding, is a great and unprecedented achievement for Isoken. Also, during the entire process, Isoken's family members do not take their time to ask her what she truly thinks about Osaze.

Another portrayal of women in the film is that they should care more about a man's financial and social standing and less about their feelings when they want to choose their husbands. This is revealed when Agnes, on hearing that Isoken also has feelings for Kevin, says to Isoken: "All these butterflies you are feeling for Kevin, na butterfly we go chop? (That is, is it butterfly we will eat?)" She goes further to say that: "Your marriage would be a union of two great Edo families. The asoebi (wedding dress) would be on flick. You can imagine Flavour and Olamide performing 
at the wedding." This portrayal, like the others, is also very bad as a man's financial and social standing cannot take precedence over feelings in matters of marriage.

Lastly, but by no means the least, is the depiction that a woman in dire need of a husband is abnormal if she decides to break up with a man. This is reflected when Isoken finally breaks up with Osaze during their pre-wedding dinner. Not only is all heavens let loose, her family members - especially her Mum and aunties - also strongly feel that something is wrong with her. Isoken's aunty says that something is wrong with her spiritually whilst her mother asks if she is gay. This portrayal, a very negative one, buttresses the way members of the Nigerian society view a woman who, at an overripe age, would break up a relationship or call off a wedding. Corollary to this is the fact that women are cheap properties meant for men in a male-dominated society. The aforesaid portrayal takes a different twist when Isoken reveals that she is in love with a white man (an oyinbo). The family members are dumbfounded and her Mum, shocked and aghast, says: "Isoken, why can't you be normal like your sisters?" Rooted in this is the depiction that a Nigerian woman should marry a Nigerian man rather than white men. Put in another way, it portrays racial discrimination.

\section{Synopsis of King of Boys}

King of Boys is a 2018 political thriller that is written and directed by Kemi Adetiba. The film runs for three hours and two minutes and stars the following persons: Sola Sobowale, Adesua 
Etomi-Wellington, Remilekun "Reminisce" Safaru, Illbliss, Toni Tones, Paul Sambo, Jide Kosoko, Sharon Ooja and Osas Ighodaro Ajibade. King of Boys centres on the life and times of Alhaja Eniola Salami (played by Sola Sobowale), who, as a young girl, suffers psychologically from bouts of domestic violence wreaked by her Dad on her Mum. She later ends up working in a restaurant where she, together with her colleagues, serves as an object of sexploitation by the male folks.

With this chequered past, Eniola grows up to become a strong, fearless, ruthless and highly connected woman. She is a business woman and philanthropist by day but at night, she rules the underworld where boys engage in several atrocities with a view to making money. With Eniola's philanthropy and connections, she is able to put a lot of politicians - one of whom is Aare - in office. But when she decides to leverage on this and pursue a political career, she is deserted and told categorically by those she has helped that the party members had reservations about her sordid past. As she tries to grapple with this, there is a twist as Makanaki, one of the boys in the underworld, eyes her crown and wants to become the king of the underworld. The battle line is drawn and Makanaki joins forces with Aare and other politicians to ensure that Alhaja Eniola Salami is brought down. 
In the long battle that ensues, as well as a display of politics, greed, hatred and deceit,

Eniola is fingered in the crimes of murder, money laundering, diversion of state funds and bribery of security agents. She is arrested and charged to court. Shortly after her discharge and acquittal by the renowned Justice Nwachukwu, she loses her adopted daughter, Kemi, to the hands of a paid assassin. Barely a day later, she loses her only son, Kitan.

But her children's death is the beginning of the worst for Eniola. She is rearrested and sent to prison whilst her accounts are frozen by the security agents. Just when she is about to be eliminated in prison by her apparently powerful adversaries, Officer Gobir, the officer working on her case, stumbles upon a string of revelations regarding the case. He helps to rescue Eniola from the cold hands of death and ensures that Aare and his accomplices are brought to book. Makanaki, Eniola's archenemy, is later killed by one of the boys in the underworld while Eniola relocates to Brooklyn in the United States of America. The film ends with Eniola ruling over the boys in the underworld in Lagos from Brooklyn, the United States.

\section{Portrayal of Women in King of Boys}

King of Boys is laden with scenes that portray women in a bad light. To start with, females in the film are depicted as objects for male gaze as well as objects for sexploitation by men. For instance, Eniola, as a young girl, had to become an object for sexual gratification by the men who 
frequented the restaurant that she worked in. Same fate is suffered by Bunmi, her friend as well as the other girls employed in the restaurant. Bunmi ends up losing her life to such sexploitation as she contracts an incurable disease believed to be AIDS. Later in the film, when Eniola refuses to marry Alhaji Salami because the latter already has a wife, the Alhaji blatantly tells Eniola that: "I can marry up to four wives." Alhaji Salami's statement here is tied to his feeling that women are cheap cargoes that a man can easily acquire for sexual gratification. This is highly demeaning to women. With regards to male gaze, most girls in the restaurant Eniola worked in as a girl dressed skimpily in order to arouse the sexual interest of the men present.

Similarly, in Eniola's first scene with Alhaji Salami, she is skimpily dressed and positions her buttocks for the Alhaji to gawk at. The Alhaji even goes ahead to ask her if that (her buttocks) are what one of his subordinates has been enjoying. This is sexploitation as well as male gaze. In a later scene, Eniola, in bed with the Alhaji, is also seductively dressed. The issue of male gaze also plays out in the scene where Kitan, Eniola's son, first meets Amaka. Amaka is skimpily dressed, with parts of her legs as well as cleavage exposed to viewers. In the same scene, the ash tray for cigarettes is a sculpted piece of a naked woman whose legs are spread: a stylish and tactful portrayal of females as objects of male gaze and sexploitation. In a later scene, Aare looks at Kemi lustfully and enthuses that: "This is the work of God." 
Besides, females in the movie are portrayed as weak and dependent: persons who cannot but be subordinates to their male counterparts. This is first seen in the life of Eniola's mother who is the victim of the regular gender-based violence from her husband. Kemi, Eniola's adopted daughter, later dies from a gunshot by a paid male assassin at the front of the court. Amaka is also throttled to death by Kitan before the latter goes ahead to commit suicide. Eniola is not left out as she goes through a lot in the hands of her male enemies. She is on the verge of losing her life to the aforesaid enemies when Officer Gobir rescues her.

Furthermore, the women in King of Boys are depicted as persons who, unlike their male counterparts, should be unambitious and unsuccessful; otherwise, they should expect reprisals from the male folks. This is obviously the reason why Eniola's struggle for political power was greeted with reprisals from not just Makanaki, but also Aare and the other political bigwigs. The men, including Inspector Shehu, are all bent on pooling Eniola down. They feel that great ambition should not be a quality of a woman and, by implication, a woman's place should be in a man's kitchen.

The aforesaid is equally the reason why the men do not give Eniola the promised position in the political sphere. These malevolent men end up truncating Eniola's political career. They orchestrate Eniola's arrest and imprisonment as well as the gruesome murder of Kemi, her daughter. At the end of the struggle, Eniola loses everything she holds dear except her very self. 
In addition, the women in King of Boys are portrayed as the "silent ones." To the men in the movie, these women should be seen but not heard. This portrayal is especially brought to the fore shortly after the death of Eniola's husband. When she walks into the underworld with boldness and orders one of the men to vacate her husband's seat (which by right is now hers), the men chorused: "Abomination!" The man in question then says: "Eniola, shut your mouth! You are bolder than a dog which has just walked into a lion's den.”

King of Boys also paints ambitious and highly successful women as bad wives. This is the reason why Eniola Salami is depicted as someone who is widowed. In the traditional Nigerian society, it is a popular belief that no responsible wife would want to be overly ambitious or delve into politics. Also, Kemi, Eniola's ambitious daughter and heir-apparent, as beautiful as she is, is portrayed as someone without a boyfriend. What can be deduced from this is that her ambitious nature is what keeps men away from her.

Finally, the women in King of Boys are portrayed as extremely dangerous, cruel and deadly. This is in contrast to the men who, to a large extent, are positively portrayed. Kemi, for example, is portrayed as a crafty, wicked and extremely dangerous girl whom no one messes with whilst her brother, Kitan, is portrayed as a spoilt but indifferent young man. In the first scene of the movie, Kemi boldly tells a senator that: "You of all people should know that my mother doesn't take 
kindly to threats. And be mindful not to touch the tail of the lion. We would get to you after the announcement has been made as promised. So, until then, Senator, try to stay out of danger. After all, Lagos can be a very dangerous city as you and your family must know." Amaka, Kitan's girlfriend, is also depicted as a very deceitful and malevolent girl. She becomes an ally of Makanaki and one of the brains behind Kemi's death.

Alhaji Eniola Salami, the protagonist, is also portrayed in the above light. In the first scene, during her birthday, she leaves the scene for an inner room where, after some verbal exchange, she flagrantly kills an ally of the opposing camp with a hammer. The picture that Eniola is very crafty and deadly runs through the other scenes and later, in the power tussle that ensues between her and Makanaki, she says: "The Yorubas always say: May God deliver us from laburu (evil). You thought that prayer was about sickness, disease, or death? That prayer was about me. I am laburu (evil), God's worst punishment in a person." Even at the end of the film, that is after all her struggles, losses, and seeming defeat, Eniola is portrayed in the same light as she rules over the boys of the underworld from Brooklyn, the U.S.A.

\section{Conclusion and Recommendation}

Despite the consistent outcry by scholars and critics that Nollywood film scriptwriters, producers and directors should desist from their regular act of portraying women in a negative 
light, the status quo has remained the same as is evident in the analysed films, Isoken and King of Boys. Females in the films are portrayed in various negative ways such as sexual objects, weak and dependent folks, to mention just a few. This depiction is diametrically opposed to the way their male counterparts in the films are portrayed.

To think that both films are directed by women calls for great concern from all who are involved in the business of film making in the Nollywood industry. If anything, female directors ought to help change the not-too-good narrative. Since it is women telling the stories of women, these female directors were supposed to tackle the prevalent stereotypical and sexist approach to women and portray them in a positive light. Could it be that the ideas of patriarchy and male dominance have been so ingrained in the minds of these female directors that they failed to look beyond such lenses whilst directing the films? Could it be that these directors decided to follow the bandwagon because only movies of such nature receive favourable outcomes in a country where patriarchy, male chauvinism and sexism are still incredibly rife?

Careful reflection reveals that the second question above holds the answer. The Nigerian audience, having been fed with films that negatively portray women for so long a time, are naturally inclined to have a preference for such films. Thus, when they come across movies that fall short of this norm, they may not want to visit the cinemas to watch them. The bitter truth is 
that the Nollywood industry needs the patronage at the box office to keep it going. Unlike Hollywood that gets subventions from the American government, Nollywood is stuck with the proceeds that come from the box office. These female directors apparently understand this; hence the reason they decided play to the status quo.

However, since viewers' perception and attitudes towards each gender are invariably shaped by the way it is presented in films, the negative portrayal of women does not bode well for

Nigerian women. To this end, the researcher strongly recommends that female directors look beyond the financial gains and exercise their right. They should make frantic efforts to appropriately tell the story of Nigerian women. Nigerian female directors should set the pace for Nigerian male directors to follow. They should change the narrative. They should, through their movies, tell the Nigerian audience that there are good things about the female gender, not the sexist junk they have been served over time. If there is any perfect time to do this, then that perfect time is now!

\section{REFERENCES}

Abbah, A. (2008). One step forward, two steps backward: African women in Nigerian video film. Communication, Culture \& Critique, 1(4), 335-357.

Adamu, A. (2007). Currying favour: Eastern media influences and the Hausa video film. Film International, 5(4), 77-89. 
Afolabi, O. \& Oyero, O. (2010). Nollywood and the Nigeria's national image: A study of some selected Nollywood movies (2010-2016). A Paper presented at the Covenant University Conference on E-Governance in Nigeria, Ota, Ogun State, June 7-9.

Agbese, A. (2010). Seeing the agenda for women's liberation or empowerment in Nigeria through movies: An analysis of Women's Cot, Women in Power and The Bank Manager. Journal of Cultural and Media Studies, 2(1), 73-78.

Aromona, O. (2016). Portrayal of African women in Nollywood films over a five-year period: A content analysis of traits applying the stereotype content model. Electronic Theses and Dissertations. Accessed at http://dc.etsu.eedu/etd/3166.

Asemah, E., Nwammuo, A. \& Uwaoma, A. (2017). Theories and Models of Communication. Jos: Jos University Press.

Brock, N. (2009). Representations of Nigerian women in Nollywood film. Unpublished PhD Thesis Submitted to the School of Postgraduate Studies, Howard University.

Elegbe, O. (2017). Women Trauma and Stereotype Tradition in Tunde Kelani's Film, Thunderbolt. CINEJ Cinema Journal, 6(2), 144-164.

Dehchenari, M., Abdullah, M. \& Eng, W. (2014). A critical and semiotic analysis of the shift in women's erotic and romantic roles in action movies and movie posters across three eras of Hollywood. Journal of Innovation Education and Research, 2(6), 25-39.

Duru, A. (2013). Ideological criticism of a Nigerian video film, August Meeting: A Feminist Perspective. Accessed at http://ejournalist.com.au/vion2/duru.pdf.

Ekwuazi, H. (2007). The Hausa video film: The call of the Muezzin. Film International, (4), 6470.

Gallagher, M. (1995). Communication and human dignity: A women's rights perspective. Media Development, 13, 6-9. 
Geena Davis Institute on Gender in Media (2015). Cinema and society; Shaping Our Worldview beyond the Lens: Investigation on the Impact of Gender Representation in Nigerian Films. Accessed at http://seejane.org/wp-content/uploads/cinema-and-society.

Harrison, K. (2003). Television viewers' ideal body proportions: The case of the curvaceously thin woman. Sex Roles, 48(5), 225-264.

Haynes, J. \& Okome, O. (1998). Evolving popular media: Nigerian video films. African Literatures, 29(3), 106-128.

Hernandez, E. (2012). Using cultivation theory to analyse college student attitudes about the dating process following exposure to romantic films. Unpublished M.A. Thesis Submitted to the Graduate Faculty of Texas Tech University.

Ibbi, A. (2017). Stereotype representation of women in Nigerian films. Cinej Cinema Journal, $6(2), 49-70$.

Ibrahim, M. (2013). Hausa film: Compatible or incompatible with Islam? Performing Islam, 2(2), 165-179.

Johnson, A. (2011). Cultivation Theory of Mass Media. Accessed at http://augusttusjohnton.

Jurfi, M. \& Dahiru, J. (2020). Muslim identity in Nigeria's cinematic culture: Analysis of select films in Nollywood and Kannywood film industry. GVU Journal of Communication Studies, 1, 116-126.

Kumwenda, G. (2007). The portrayal of witchcraft, occults and magic in popular Nigerian video films. Unpublished Masters Dissertation Submitted to the Faculty of Arts, University of Witwaterstrand.

Langford, T. \& Mackinnon, N. (2000). The affective bases for the gendering of traits: Comparing the United States and Canada. Social Psychology Quarterly, 63, 34-48.

Matei, S. (2012). Communication Theory and Mass Communication Research from Left to Right. Accessed at http://matei.org/ithink/2012//11/08/cultivation-theory-and-masscommunication-research-from-left-to-right. 
Morgan, M., Signorielli, N. and Shanahan, J. (2002). Growing up with television: Cultivation processes. In Bryant, J. \& Oliver, M. (Eds.). Media Effects: Advances in Theory and Research. New York: Routledge.

Nwuneli, O., Okoye, I., Okunna, C. \& Ayo, J. (1993). Media use, knowledge of world affairs and image of nations among Nigerian youths. Africa Media Review, 7(1), 33-49.

Ogunranti, C. (1981). The role portrayal of women in television advertisement: The Nigerian case. Unpublished Masters Dissertation Submitted to the School of Postgraduate Studies, University of Lagos.

Okunna, C. (1996). Portrayal of women in Nigerian home video films: Empowerment or Subjugation? Africa Media Review, 10(3), 21-36.

Okuyade, O. (2011). Women and evangelical merchandising in the Nigerian filmic enterprise. Kemanusiaan, 18(1), 1-14.

Olupohunda, B. (2013). Stop the Violence against Nigerian Women in Nollywood. Accessed at http://www.secureavaaz.org/en/petition/stop-the-violence.

Omatsola, D. (2016). The semiotics of feminism and Nigeria's cultural identity in Nollywood: Women's Cot in Focus. Covenant Journal of Communication, 3(1), 1-22.

Onyenankeya, K., Onyenankeya, O. \& Osukunle, O. (2019). Sexism and gender profiling: Two decades of stereotypical portrayal of women in Nollywood films. Journal of International Women's Studies, 20(2), 73-90.

Perkins, T. (2000). Who (and what) is it for? In Christian, G. and Linda, W. (Eds.). Reinventing Film Studies (pp. 112-126). New York: Oxford University Press.

Ukata, A. (20100. Conflicting framings of women in Nollywood videos. African Nebula, 1(1), 6775. 
Uzuegbunam, C. and Ononiwu, C. (2018). Highlighting racial discrimination in 3D animated films and its implications: A semiotic analysis of Frankenweenie. Romanian Journal of Communication and Public relations, 20(2), 5-20.

Vinney, C. (2019). Cultivation theory. Accessed at http://www.thoughtco.com/cultivation-theorydefinition-4588455.

Zaharopoulos, T. (2001). Traditional family relationships and television viewing in Greece. TBS Archives, 6, 8-16. 